\title{
PROJECT FINANCING OF THE WATER SECTOR IN BULGARIA
}

\author{
Z. Stoyanova ${ }^{1}$, I. Petkova ${ }^{2}$ \\ ${ }^{1}$ Natural Resource Economic Department, Business Faculty, University of National and World \\ Economy, Sofia, Bulgaria \\ ${ }^{2}$ Financial Control Department, Finance And Accountancy Faculty, University of National and World \\ Economy, Sofia, Bulgaria
}

\begin{abstract}
During the programming period 2014-2020, new opportunities for the water sector appear through using the funds from OPE 2014-2020, axis Water. The aim of the paper is to analyze and assess the project funding in the water sector for the period 2007-2013. On this basis are made conclusions of the program period and recommendations for improvement the sector's potential by using project financing. The first part of the paper analyzes and assesses the use of funds for the development of the water sector during the period 2007-2013. On the basis of a survey of beneficiaries of OPE 2007-2013 the second part of the paper assess the OPE 2007-2013, axis Water. Based on the analysis and assessment are made recommendations for improvement of the project financing in the water sector. Conclusions in the paper are based on the results of university research project "Project management of sustainable development of water sector" (UNWE) (Stoyanova, 2015) and information from Ministry of the environment and water.
\end{abstract}

Key words: project financing, water sector

\section{INTRODUCTION}

The projects in water sector require specific state support and a specific type of management because of their features. They are characterized by capital intensity as they require high initial investment and the period of return in long term. According to some authors (Ilies et all, 2010), rates of return in the water sector are among the lowest compared to other sectors due to late returns and low sensitivity to tariff increases in the water sector. However in recent years the projects in the water sector have relatively good rate of return. Some projects, especially those related to waste water and hydropower are among the most capital-intensive in terms of investment in infrastructure. Very often the projects in the water sector are associated with long legal procedures and this complicates and prolongs the period of implementation. This could be associated with different procedures as establishment of rights of construction, land acquisition procedures, permits and statements from the competent authorities and others.

The integration of sustainability in the

\footnotetext{
* Correspondence to: Zornitsa Stoyanova, Bulgaria, Sofia, Studentski grad, ul. Hristo Botev, +35928195460,e-mail : zstoyanova@unwe.bg
}

management of projects in the water sector requires the implementation of an integrated approach to project management, not only from a technical point of view but also in terms of organizational factors (Daneshpour, 2015). Organizations strive to achieve more sustainable and environmentally friendly approach in their projects and in this regard the concept of sustainable development is expected to reflect in the project management. The management of traditional projects and sustainable management of projects are quite different in some points. Key points in the conventional project management are based on time scale, budget and scope (in terms of quality), while the sustainable management of projects in water sector is complicated due to the integration of the three spheres of sustainability - social, environmental and economic in the traditional concept. In this regard the impact of the principles of sustainability on the project management leads to shift the scope of project management. Social and environmental direction in the sustainable approach increases the requirements of quality management approach and they face numerous challenges in the future. There is a growing need for knowledge to apply in practice the concept of sustainability in project management. 
Sustainability incorporates the harmonization of social, environmental and economic spheres and businesses should try to satisfy each of them, while the traditional method of project management focuses on three constraints time, costs and scope.

The sustainability concept stress the focus on the long and short term periods, while longterm vision is beyond the scope of traditional project management. Sustainability requires natural capital not to be exploited and businesses have to manage adequately its social and environmental capital. As reports on the progress of the project logically follow the definition of the scope, objectives, critical factors, business orientation, etc., reporting of project activities also are influenced by the inclusion of sustainability aspects in the project planning. The sustainability concept is also reflected in the Operational Programme Environment (OPE) 2007-2013 through its objectives and priorities, based on the EU environmental policy and reflecting both Bulgaria's international commitments in the environmental sector and the commitments made to the EU during the pre-accession period.

A number of specific regulatory documents influence on the implementation of policies related to project financing in water sector. It is important to note that large projects, especially in water sector, are managed on a decentralized basis. In this regard, the EU legal framework for the programming period 2007-2013 for the absorption of Structural Funds, focusing on the improvement of financial management and control, is related to Council Regulation (EC) No 1083/2006 and the Commission Regulation No. 1828/2006 specifying order and the way for its implementation. Important documents for the management of the projects in the water sector are Regulation (EC) No 1083/2006 and Regulation No. 1828/2006 on the procedure and method of implementation of Regulation (EC) No 1083/2006. They are related to programming as an essential stage of the operational programs and the funds for their implementation.

Both regulations generally focus on the allocation of funds within the program period and linking the planned in the Operational Programs measures and activities with the National Strategic Reference Framework (Petkova, 2015). This is reflected in national legislation. At the same time, articles 8-10 of the Decree of the Council of Ministers No 121 of 2007 laying down the procedure for the award of grants under the Operational
Programs co-financed by the Structural Funds and under the EU PHARE Program, stipulate requirements for the planning of the activities under the operational programs, in the direction of the functions and tasks of the administration that manages them. This decree sets out an important key condition related to the budget of the Operational Program and its measures. In addition to the requirement to develop an indicative annual work program (IAWP), it is necessary to link this work program to the average annual budget plan. This is extremely useful and important for beneficiaries who can prepare themselves to participate in the application procedures. Thus, municipalities have sufficient time resources to take the necessary management decisions with the municipal council for preparation and planning the project proposals. An important point in the decree is the development of an annual plan by the Managing Authority (MA) and the Intermediate Body (IB), and its reporting. This makes it possible to trace the actions of the Managing Authority and the Intermediate Body, as well as it is an opportunity to predict the further procedures ahead of the beneficiaries (Petkova, 2015).

Regulation (EC) No 1083/2006 is essential for project financing in the water sector. In Art. 57 of the Regulation are set out a conditions for ensuring the sustainability of the operations and the contribution of the Funds as well as the specificities related to the financing of revenue-generating projects. This Regulation is important because it is related to project selection conditions, the conditions for determination the sustainability of the investment in the development of the costbenefit analysis. In this regard it is connected with water projects because they require preparation a cost-benefit analysis that is mandatory.

\section{METHOLOGICAL FRAMEWORK}

The aim of the paper is to analyze and assess the project funding in the water sector for the period 2007-2013. On this basis are made conclusions of the program period and recommendations for improvement the sector's potential by using project financing.

To realize the aim of the paper were made: 1) Literature review on the specific features of water projects in the context of project financing; 2) State and analysis of the fund distribution of axis Water for the period 20072013; 3) Evaluation of the OPE 2007-2013, axis 1 Water on opinion of project beneficiaries of the Programme; 4) Based on the aggregated 
and analyzed information are offered recommendations and general conclusions.

Information is summarized on the basis of strategic documents of the OPE 2007-2013, axis 1, Water and structured interviews with beneficiaries of OPE,axis 1 Water 2007-2013.

The survey was conducted in the period JuneSeptember 2016 in order to analyze the project financing in water sector and evaluate the problems by implementation of measures under axis 1 Water from OPE 2007-2013.

Conclusions in the paper are based on the results of university research project "Project management of sustainable development of water sector" (UNWE) (Stoyanova et all, 2015) and information from Ministry of the environment and water.

\section{STATE OF PROJECT FINANCING UNDER OPE 2007-2013, AXIS 1WATER}

In the beginning of 2016, the overall amount of funds contracted under the priority axis stood at nearly BGN 2,9 billion (over $122 \%$ of the funding for the sector). Funds paid amounted to BGN 2.434 billion (over $103 \%$ of the funding for the sector) (MEW, 2014).

142 projects were successfully completed with a grant in the amount of BGN 724 million absorbed, of which contracts under the technical assistance procedure for preparation of investment projects, contracts for improvement and development of water supply and wastewater infrastructure are in the municipalities of Burgas, Valchi Dol, Varshets, Glavinitsa, Kavarna, Pernik, Popovo, Primorsko, Sofia Municipality, Ruen, Hisarya and Troyan, the project of the Basin Directorate - Blagoevgrad for development of river basin management plans.

Financed under the funding of the Environment Operational Programme 20072013 are construction and reconstruction of 50 wastewater treatment plants.

The municipalities with the highest share of approved projects from the total number of approved projects in Bulgaria under Axis 1 were Plovdiv, Sofia, Bourgas with respectively $11.3 \%, 10.1 \%$ and $8.5 \%$. At least approved projects were observed in the municipalities of Sliven - $0.4 \%$, Pernik- 1.2\%, Razgrad - $1.6 \%$. The highest share of rejected projects is observed in Burgas, Kardzhali and Sofia.
In regards to the amount of the contracted funds, the sources by measure "Improvement and development of drinking water and waste water infrastructure in agglomerations with over 10000 PE" - 53,3\% has the highest share in the total financing, while the lowest share have the funds by measures "Strategic planning and strengthening the capacity of the structures are involved in process of reforming the water sector to ensure sustainable management of water infrastructure" and "Development of plans for management of flood risk", respectively, with $0.5 \%$ (Table 1). Similar is the distribution of the final amount of funding by these measures. With a high share of the funds that were finally allocated to Axis 1 is also the measure "Improvement and development of water and wastewater infrastructure for agglomerations with over10,000 pe" - $25,1 \%$.

The share of the amount paid at the end of operation by measure "Development of plans for management of flood risk" is the lowest only $0.1 \%$. The share of amount paid at the end of operation from the contracted funds ranged from $0.8 \%$ by measure "Preparation and implementation of projects for improvement and development of water and wastewater infrastructure in agglomerations with over 10000 pe" to $60.3 \%$ under the measure "Improvement and development of water and wastewater infrastructure for agglomerations with over10,000 pe". A high share of amount paid at the end of operation from the contracted funds is observed by measure "Technical assistance for development of investment projects" under priority axis 1 of OPE 2007 to $2013-54.4 \%$.

\section{EVALUATION OF THE PROJECT FINANCING UNDER OPE 2007-2013, AXIS 1WATER}

The evaluations of measures under Axis 1Water from OPE 2007-2013 are positive as a whole (Table 2). A positive opinion on the measures is expressed by $5 \%$ of the respondents and $50 \%$ are "agreeing to some extent" that the measures are good and do not need any corrections. Most of the respondents $65 \%$ consider that the implementation of the measures is highly bureaucratic (40\% agree to some extent and $25 \%$ totally agree). $80 \%$ of the respondents agree totally or partially that the procedures take too long time, and $70 \%$ believe that the required documents are very complicated. Half of respondents agree in partially with the statement that serious corrections are required in application procedures. 
STOYANOVA Z., et al.

Table 1. Amount of contracted funds by OPE, amound paid at the end of operation and share of amount paid at the end of operation from the contracted funds, OPE 2007-2013, axis 1

\begin{tabular}{|c|c|c|c|}
\hline Measure & $\begin{array}{l}\text { Share of } \\
\text { the total } \\
\text { contracted } \\
\text { amount, \% }\end{array}$ & $\begin{array}{l}\text { Share of the } \\
\text { total amount } \\
\text { paid at the end } \\
\text { of operation, } \\
\%\end{array}$ & $\begin{array}{l}\text { Share of amount } \\
\text { paid at the end of } \\
\text { operation from } \\
\text { the contracted } \\
\text { funds, } \%\end{array}$ \\
\hline $\begin{array}{l}\text { Technical assistance for development of } \\
\text { investment projects under priority axis } 1 \text { of OPE } \\
2007-2013\end{array}$ & 2,9 & 5,4 & 54,4 \\
\hline $\begin{array}{l}\text { Improvement and development of water and } \\
\text { wastewater infrastructure for agglomerations with } \\
\text { over } 10,000 \text { pe }\end{array}$ & 12,3 & 25,1 & 60,3 \\
\hline Development of river basin management plans & 0,9 & 0,8 & 27 \\
\hline $\begin{array}{l}\text { Preparation and implementation of projects for } \\
\text { improvement and development of water and } \\
\text { wastewater infrastructure in agglomerations with } \\
\text { over } 10000 \text { pe }\end{array}$ & 21,6 & 0,6 & 0,8 \\
\hline $\begin{array}{l}\text { Improvement and development of drinking water } \\
\text { and waste water infrastructure in agglomerations } \\
\text { with over } 10000 \mathrm{PE}\end{array}$ & 53,3 & 55,5 & 30,8 \\
\hline $\begin{array}{l}\text { Strategic planning and strengthening the capacity } \\
\text { of the structures involved in process of reforming } \\
\text { the water sector to ensure sustainable } \\
\text { management of water infrastructure }\end{array}$ & 0,5 & 0,5 & 30,9 \\
\hline $\begin{array}{l}\text { Development of plans for management of flood } \\
\text { risk }\end{array}$ & 0,5 & 0,1 & 3,2 \\
\hline $\begin{array}{l}\text { Measures to increase the capacity to prevent and } \\
\text { fight floods and monitoring and protection of } \\
\text { waters used for shipping activity }\end{array}$ & 2,5 & 2,6 & 29,9 \\
\hline $\begin{array}{l}\text { Measures to improve air quality by providing } \\
\text { environmentally friendly vehicles of the public } \\
\text { transport }\end{array}$ & 5,5 & 9,5 & 51,5 \\
\hline Total & 100 & 100 & - \\
\hline
\end{tabular}

Source: MEW, 2014

Table 2. Evaluation of measures under axis 1 Water from OPE 2007-2013

\begin{tabular}{|l|c|c|c|c|c|}
\hline \multicolumn{1}{|c|}{ Evaluation } & $\begin{array}{l}\text { Totally } \\
\text { disagree }\end{array}$ & $\begin{array}{l}\text { Partially } \\
\text { disagree }\end{array}$ & $\begin{array}{l}\text { Without } \\
\text { opinion }\end{array}$ & $\begin{array}{l}\text { Partially } \\
\text { agree }\end{array}$ & $\begin{array}{l}\text { Totally } \\
\text { agree }\end{array}$ \\
\hline $\begin{array}{l}\text { They are good and do not need } \\
\text { any correction }\end{array}$ & $0 \%$ & $35 \%$ & $10 \%$ & $50 \%$ & $5 \%$ \\
\hline $\begin{array}{l}\text { The implementation of the } \\
\text { measures is highly bureaucratic }\end{array}$ & $5 \%$ & $15 \%$ & $15 \%$ & $40 \%$ & $25 \%$ \\
\hline Procedures take too long & $0 \%$ & $20 \%$ & $0 \%$ & $40 \%$ & $40 \%$ \\
\hline $\begin{array}{l}\text { Required documents are very } \\
\text { complicated }\end{array}$ & $15 \%$ & $15 \%$ & $0 \%$ & $50 \%$ & $20 \%$ \\
\hline $\begin{array}{l}\text { Serious corrections are required in } \\
\text { application procedures }\end{array}$ & $10 \%$ & $25 \%$ & $10 \%$ & $50 \%$ & $5 \%$ \\
\hline $\begin{array}{l}\text { The content of the measures is } \\
\text { inconsistent with the needs of } \\
\text { society }\end{array}$ & $30 \%$ & $20 \%$ & $20 \%$ & $30 \%$ & $0 \%$ \\
\hline
\end{tabular}

Source: own research

In regards to the evaluation of the main difficulties faced by beneficiaries in the process of preparation of the documents required for application for projects under OPE, Axis 1, none of the beneficieries had any difficulties which constrain the successful realizing of the activity (except of $5 \%$ of the respondents mentioning this response for "Approval of expenditure by MOEW") (Table 3). $37 \%$ of the beneficiaries had not difficulties in finding a consultant to prepare / support the project proposal and 37\% had the usual minor 
difficulties typical for such kind of activities. Only 5\% from the respondents had significant difficulties in this activity that have affect the quality of the activity. The formation of a project management team was not a constraine for a lot of the beneficiaries. 35\% of them had not difficulties, and $40 \%$ had only usual minor difficulties. Nearly half of the beneficiaries had some difficulties in preparing the tender documents for conducting PPL procedures, conducting tender procedure for selection of contractors and signing of a contract, as well as technical assistance for pre-investment research, EIA, working design, financial analysis, but these dificulties did not affect the qualitative performance of the activity.

Table 3. Evaluation of the difficulties experienced by beneficiaries in the process of preparation of the documents necessary for applying for the OPE project / projects 2007-2013, Axis 1

\begin{tabular}{|l|l|l|l|l|l|}
\hline Project preparation activities & $\mathbf{1}$ & $\mathbf{2}$ & $\mathbf{3}$ & $\mathbf{4}$ & $\mathbf{5}$ \\
\hline Finding a consultant to prepare / support the project proposal & 37 & 37 & 21 & 5 & 0 \\
\hline Forming a project management team & 35 & 40 & 15 & 10 & 0 \\
\hline $\begin{array}{l}\text { Preparation of tender documents for conducting procedures under } \\
\text { the PPA, conducting tender procedure for selection of contractors } \\
\text { and signing of a contract }\end{array}$ & 5 & 37 & 47 & 11 & 0 \\
\hline $\begin{array}{l}\text { Technical assistance for pre-investment research, EIA, working } \\
\text { design, financial analysis, preparation of tender documents and } \\
\text { application forms }\end{array}$ & 11 & 32 & 47 & 10 & 0 \\
\hline Procedures for the issuance of permits under the Water Act & 11 & 37 & 37 & 15 & 0 \\
\hline Conformity assessment procedures & 16 & 42 & 37 & 5 & 0 \\
\hline Procedures for the issuance of building permits & 16 & 53 & 26 & 5 & 0 \\
\hline Preparation and approval of detailed development plans & 16 & 37 & 42 & 5 & 0 \\
\hline Ensuring regulatory readiness to start designing & 11 & 47 & 37 & 5 & 0 \\
\hline $\begin{array}{l}\text { Preparation of financial and economic analysis and cost-benefit } \\
\text { analysis }\end{array}$ & 5 & 26 & 53 & 16 & 0 \\
\hline Conclusion of the contract with MOEW & 45 & 35 & 10 & 10 & 0 \\
\hline Approval of expenditure by MOEW & 5 & 45 & 30 & 15 & 5 \\
\hline
\end{tabular}

1- We had no difficulties; 2-We had the usual minor difficulties typical of such activities; 3-We had some difficulties, but they did not affect the quality of the activity; 4 - We have had significant difficulties that have affected the quality of the activity; 5 -We had difficulties that constrained the success of the activity

Source: own research

Regarding the procedures for issuing permits under the Water Act and for conformity assessment, the beneficiaries had the usual minor difficulties typical for such kind of activities (respectively 37 and 42\%) and some difficulties that did not affect the quality of the activity ( $37 \%$ of the respondents). About $18 \%$ had not difficulties in the different activities of the project. The procedures for issuing building permits create usual minor difficulties for $53 \%$ of the beneficiaries. The conclusion of the contract with the MOEW and the approval of the costs by the MOEW do not create any particular difficulties in the preparation of the projects. Only $10 \%$ of the respondents indicate that they had significant difficulties that affected the quality of the activity at the conclusion of the contract and $15 \%$ when the MOEW approved the expenditures.

\section{GENERAL CONCLUSION AND RECOMMENDATION}

Based on the analysis of the fund distribution of the axis 1: Improvement and development of water and wastewater infrastructure and improvement of air quality from the OPE
2007-2013 and on beneficiary's assessment of OPE 2007-2013 could be made general conclusions and recommendations as follows:

$\checkmark$ The municipalities with the highest share of approved projects from the total number of approved projects in Bulgaria under Axis 1 are Plovdiv, Sofia, Bourgas by around $10 \%$ of each. At least approved projects were observed in the municipalities of Sliven, Pernik, Razgrad - around only $1 \%$ of the total number approved projects.

$\checkmark$ Measures "Improvement and development of water and wastewater infrastructure for agglomerations with over10,000 pe" and "Technical assistance for development of investment projects under priority" become most significant support from OPE 2007-2013 according to amount paid at the end of operation and support for the measure "Development of plans for management of flood risk" is the lowest. A large part of the financial resources of OPE is directed primarily to the construction of sewage networks for treatment facilities in agglomerations with more than $2000 \mathrm{PE}$ for which the transition period expires on 
31.12.2014. This is explained by the fact that the objectives set in Sectoral policies have not been met within the deadlines.

$\checkmark \quad$ A large number of beneficiaries evaluate measures under Axis 1 Water as highly bureaucratic. They consider that the procedures take too long time and the required documents are very complicated. Half of the respondents agree partially with the statement that application procedure requires serious corrections.

$\checkmark \quad$ Regarding the evaluation of the main difficulties, which the beneficiaries had in the process of preparation of the documents required for application of the project / projects under OPE 2007-2013, Axis 1, none of the beneficiaries had any difficulties, which constrain the successful performance of the activity. Nearly half of the beneficiaries had some difficulties in preparing the tender documents for conducting PPL procedures, conducting tender procedure for selection of contractors and signing of a contract, as well as technical assistance for pre-investment research, EIA, working design, financial analysis, but they did not affect the qualitative performance of the activity. Procedures for issuing building permits create the usual minor difficulties for more than half of the beneficiaries.

$\checkmark$ The established national legal framework for management of OPE is in line with the EU regulations and covers the main steps of the Community funds management process. However, it is necessary to overcome the main problems faced by the beneficiary municipalities. In this connection, its quality and systematic development, detailed exhaustiveness and timeliness could be improved.

$\checkmark \quad$ The difficulties that constrained the beneficiaries could be overcome through training related to the cost-benefit analysis, the specific regulatory framework connected with the water sector, the implementation of the Public Procurement Act, the preparation of infrastructure projects for applying for grants.

\section{REFERENCES}

1. Daneshpour, H. Integrating Sustainability into Management of Project. International Journal of Environmental Science and Development, Vol. 6, No. 4, 321-325,2015.

2. 2.Ilies, L., Crisan, E., Muresan, I. Best Practices in Project Management. Review of International Comparative Management. 11( 1), 43-51,2010.

3. 3.MEW, List of Beneficiaries Operational Programme Environment 2007 - 2013, 2014,

http://ope.moew.government.bg/files/useru ploads/files/projects/list_of_beneficiaries_a 1l_bg_062014.pdf.

4. Petkova I., European projects, politics and normative regulations. Pub. Forkom.2015.

5. 5.Stoyanova, Z., Doichinova, J., Kanchev, I., Jecheva, I., Atanasov, B., Todorova, K.Project management of sustainable development of water sector. Research project, NID NI1-7/2015. University of national and world economy. Sofia. Bulgaria,2015. 